\title{
Gérard Dessons, Maeterlinck, le théâtre du poème
}

\section{Fabio Scotto}

\section{(2) OpenEdition}

\section{Journals}

\section{Edizione digitale}

URL: http://journals.openedition.org/studifrancesi/10590

DOI: 10.4000/studifrancesi. 10590

ISSN: 2427-5856

\section{Editore}

Rosenberg \& Sellier

\section{Edizione cartacea}

Data di pubblicazione: 1 décembre 2017

Paginazione: 581

ISSN: 0039-2944

\section{Notizia bibliografica digitale}

Fabio Scotto, «Gérard Dessons, Maeterlinck, le théâtre du poème», Studi Francesi [Online], 183 (LXI | III) | 2017, online dal 01 février 2018, consultato il 23 janvier 2021. URL: http://journals.openedition.org/ studifrancesi/10590 ; DOI: https://doi.org/10.4000/studifrancesi.10590

Questo documento è stato generato automaticamente il 23 janvier 2021.

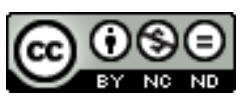

Studi Francesi è distribuita con Licenza Creative Commons Attribuzione - Non commerciale - Non opere derivate 4.0 Internazionale. 


\title{
Gérard Dessons, Maeterlinck, le théâtre du poème
}

\author{
Fabio Scotto
}

\section{NOTIZIA}

GÉRARD DESSONS, Maeterlinck, le théâtre du poème, Paris, Classiques Garnier, 2016, «Études sur le théâtre et les arts de la scène» 3, 187 pp.

1 Studioso di poesia e poetica e di teoria dell'arte e del ritmo allievo di Henri Meschonnic, Gérard Dessons, professore a Paris 8, qui si confronta con l'opera del grande drammaturgo belga riproponendo in una versione rivista, corretta e accresciuta un suo saggio edito da Laurence Teper nel 2005.

2 Proprio a Henri Meschonnic l'A. deve la nozione di poème, inteso, oltre ogni distinzione di genere tra verso e prosa, come quanto promana dalla storicità di un soggetto all'opera che si costruisce nello scrivere; ecco allora, già dall'epigrafe liminare, il richiamo al teatro come poème in un'intervista dello stesso Maeterlinck, a indicare l'asse teorico dominante dell'analisi intrapresa.

3 Strutturata in otto capitoli, l'opera percorre l'avventura teatrale del poeta e drammaturgo alla luce di un approccio teso a cogliere, anche mediante taluni neologismi critici, l'invisibile, l'irrappresentabile e il silenzio, vero motore dell'azione verbale e performativa, il quale, come nella poesia, contribuisce alla creazione di un continuo, se, come afferma il qui citato Pierre Van den Heuvel, «le silence, en tant qu'acte de la non-parole ne produit pas un énoncé linguistique, mais un vide textuel, un blanc, un manque qui fait partie intégrante de la composition et qui signifie autant ou plus que la parole actualisée» (p. 65).

4 In tal modo una metrica della prosa strutturata per catene prosodiche affiora dal phrasé delle pièces di Maeterlinck, le cui modalità semantizzano il silenzio e ritmizzano il verbo, per divenire un'etica che fa del teatro «un acte ordinaire de la vie» (p. 171), il suo tragico quotidiano d'un tratto scosso da un evento inatteso, straordinario, il quale fa 
dell'arte drammatica lo scenario di un ascolto, un'attività del senso all'opera nell'opera, la sua voce, «l'immense puissance d'une parole dite» (p. 174). 